\title{
KAJIAN SISTEM IMUNITAS UNTUK PENGENDALIAN PENYAKIT PADA IKAN DAN UDANG
}

\author{
Inem Ode \\ Staf Pengajar FPIK UNIDAR-Ambon, e-mail: -
}

\begin{abstract}
ABSTRAK
Setiap adanya infeksi mikroorganisme baik bakteri, virus dan parasit maupun jamur ke dalam tubuh, maka ikan atau udang akan memberikan respon dengan sistem pertahanan tubuh. Pada ikan sistem pertahanan tubuh terdiri dari Sistem pertahanan innate atau sistem pertahanan bawaan /alami yang bereaksi pada semua bahan yang asing bagi tubuh seperti kolonisasi dan infeksi oleh organisme patogen. Sistem pertahanan ini juga disebut sistem pertahanan non spesifik dan Sistem pertahanan dapatan atau yang diinduksi (Acruired) yaitu sistem pertahanan yang akan berfungsi dengan baik harus diinduksi antara lain dengan lain dengan pemaparan pada patogen atau produk-produk yang berasal dari patogen (misalnya : LPS dan vaksin). Berbeda dengan ikan, pada udang tidak mempunyai antibodi oleh karena itu pertahanannya tertumpu pada sistem kekebalan alami.
\end{abstract}

Kata Kunci: Sistem kekebalan, imunitas.

\section{PENDAHULUAN}

Sistem Imunitas atau kekebalan adalah Mekanisme pertahanan diri terhadap partikel asing / Patogen. Setiap adanya infeksi mikroorganisme baik bakteri, virus dan parasit/jamur ke dalam tubuh, maka ikan atau udang akan memberikan respon dengan sistem pertahanan tubuh.

Pada ikan Sistem kekebalan tubuh terdiri dari :

- Sistem pertahanan innate atau sistem pertahanan bawaan /alami yang bereaksi pada semua bahan yang asing bagi tubuh seperti kolonisasi dan infeksi oleh organisme patogen. Sistem pertahanan ini juga disebut sistem pertahanan non spesifik

- Sistem pertahanan dapatan atau yang diinduksi (Acruired) yaitu sistem pertahanan yang akan berfungsi dengan baik harus diinduksi antara lain dengan pemaparan pada patogen atau produkproduk yang berasal dari patogen (misalnya : LPS dan vaksin). Sistem pertahanan ini juga disebut pertahanan spesifik yang hanya bereaksi pada antigen tertentu.
Ikan telah diketahui lebih mengandalkan mekanisme sistem kekebalan non-spesifiknya /alamiah /bawaan (innate immune system) dari pada sistem kekebalan spesifiknya (Anderson, 1992). Pertahanan non-spesifik merupakan sistem pertahanan tubuh yang sangat penting pada sistem kekebalan tubuh ikan. Pada ikan, respon imun baru terbentuk secara sempurna manakala ikan telah dewasa. Ikan-ikan muda tidak mempunyai respon imun spesifik yang sempurna (Ellis, 1999) dan bergantung pada respon selular non-spesifik untuk bertahan dari serangan infeksi mikroba. Pertahanan nonspesifik merupakan pertahanan utama pada ikan stadia benih dan ikan muda (Vadstein, 1997).

Sebagaian besar sistem pertahanan tubuh pada ikan berupa protein seperti antibodi, Mayor Histocompatability Complex (MHC), protein reseptor baik sel $B$ atau sel $T$ dan lainlainnya. Protein-protein dalam komponen sistem pertahanan tubuh ikan dikode dengan suatu gen yang terletak pada DNA inti atau DNA kromosomal. Gen-gen tersebut akan diaktifkan ketika sel mendapatkan rangsangan berupa infeksi mikroorganisme, untuk 


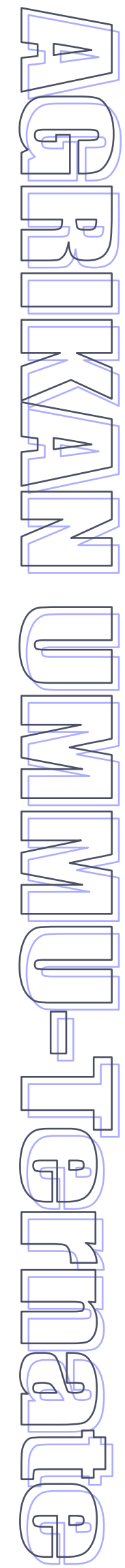

disintesis menjadi mRNA yang mengkode protein-protein yeng berhubungan dengan sistem pertahanan tubuh. Kemudian proteinprotein tersebut akan bekerja sesuai dengan perannya masing-masing untuk mendegradasi antigen yang masuk. Ketika antigen telah didegradasi oleh protein sistem pertahanan tubuh tadi, gen-gen tersebut akan dinonaktifkan sehingga sintesis mRNA yang mengkode protein dihentikan (http://id.wikipedia.org/immunity).

Udang, sama dengan invertebrate lainnya tidak mempunyai antibodi oleh karena itu pertahanannya tertumpu pada sistem kekebalan alami, yang kemampuannya hanya mengenali benda-benda asing dan meresponnya dengan melawan dan merusak mikroorganisma penyerang.

\section{SISTEM KEKEBALAN PADA IKAN}

\subsection{Komponen sistem Imun non Spesifik}

Sistem imun non-spesifik ikan antara lain terdiri dari penghalang fisik terhadap infeksi, pertahanan humoral dan sel-sel fagositik (leukosit granulosit dan agranulosit). Ikan teleostei memiliki sejumlah penghalang fisik terhadap infeksi antara lain kulit dan mukus. Mukus memiliki kemampuan menghambat kolonisasi mikroorganisma pada kulit, insang dan mukosa. Mukus ikan mengandung imunoglobulin (IgM) alami, bukan sebagai respon dari pemaparan terhadap antigen. Imunoglobulin (antibodi) tersebut dapat menghancurkan patogen yang menginvasi (Irianto, 2005). Adapun sisik dan kulit merupakan pelindung fisik yang melindungi ikan dari kemungkinan luka dan sangat penting perannya dalam mengendalikan osmolaritas tubuh. Kerusakan sisik atau kulit akan mempermudah patogen menginfeksi inang. Mukus selain sebagai pelindung fisik juga pelindung kimiawi karena mengandung lisozim, komplemen, protein-protein komplemen dan protease mirip tripsin yang dapat merusak sel-sel bakteri Gram negatif. Lisozim dapat menghancurkan dinding sel bakteri (peptidoglikan), komplemen akan menyerang pada lapisan ganda lipid (lipid bilayer) pada dinding sel, protein reaktif-C mengaktivasi komplemen, sedangkan anti protease akan menetralisasi eksotoksin.
Meskipun memiliki perlindungan fisik, antigen dapat masuk melalui permukaan epitel yang rusak, insang (terutama sesudah terjadinya stress osmotik), organ linea lateralis dan saluran pencernaan. Jika patogen telah masuk ke dalam tubuh, maka beragam respon pertahanan non-spesifik dan adaptif akan menghadangnya, respon tersebut berasal dari lisozim, komplemen, transferin, lektin, tripsin, (di dalam lapisan sel-sel epitel kulit, insang dan intestinum), makroglobulin, precipitin, serum amyloid A (SAA), dan serum amyloid P (SAP) (Ellis, 1999).

Pertahanan non-spesifik utama lainnya yaitu berupa sel-sel fagositik, yang utamanya terdiri dari monosit (prekursor-prekursor makrofag), makrofag dan granulosit (leukosit granular : neutropil, basofil dan eosinofil) (Robersen,1999). Monosit mengalami sirkulasi, adapun makrofag terikat pada jaringan. Aktivitasnya antara lain yaitu opsonisasi antigen. Untuk menjalankan aktivitasnya, monosit memerlukan hadirnya reseptor Fc untuk mengikat antibodi. Granulosit sendiri jika pada mamalia tersusun atas neutrofil, eosinofil dan basofil. Pada ikan teleostei, meskipun komponen granulosit sama tetapi asidofil dan basofil jumlahnya sangat rendah dan tidak mengalami sirkulasi. Jumlah neutrofil, basofil dan asidofil sangat bervariasi diantara spesies ikan. Pada ikan salmonid, neutrofil predominan, sedangkan asidofil dan basofil jumlahnya sangat rendah atau bahkan tidak ada. Pada ikan cyprinus carpio hanya neutrofil saja yang jumlahnya melimpah yaitu sekitar $8 \%$ sedangkan basofil dan heterofil hanya $1 \%$ saja. Adapun pada plaice (Pleuronectes platessa) dan Anguilla spp., hanya dijumpai neutrofil saja (Irianto, 2005).

Sel-sel fagosit akan mengenali dan menelan partikel-partikel antigenik, termasuk bakteri dan sel-sel inang yang rusak melalui tiga tahapan proses yaitu pelekatan, fagositosis dan pencernaan. Pelekatan pada permukaan sel bersifat selektif dan sel-sel inang yang sehat tidak akan ditelan karena adanya mekanisme pengecualian tipe I MHC (MHC Type I exclusion mechanism) meskipun identifikasi gen-gen MHC terbatas pada beberapa spesies saja. 


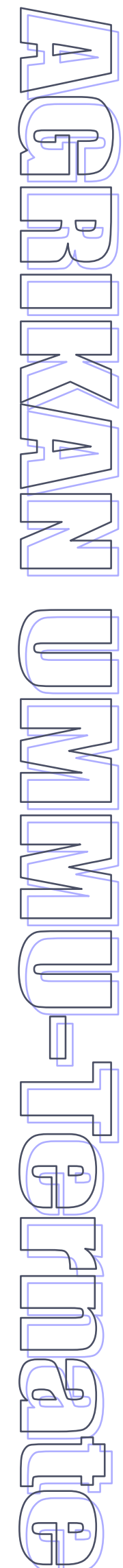

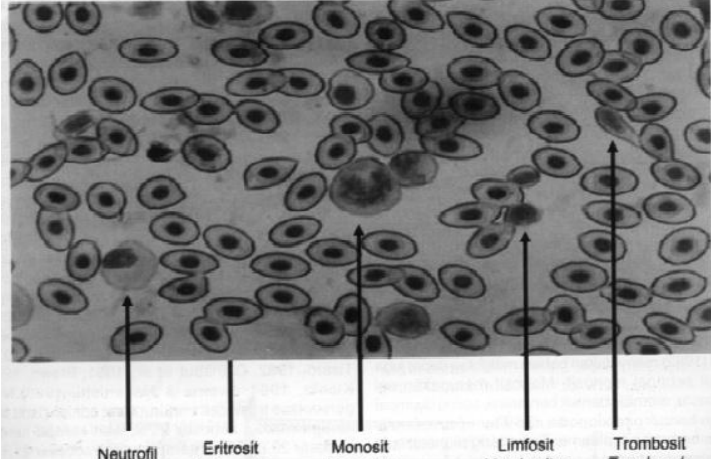

Gambar 1. Morfologi sel-sel fagosit

Inflamasi merupakan suatu respon seluler non-spesifik terhadap invasi patogen atau toksin. Inflamasi ditandai dengan rasa sakit, pembengkakan, kulit memerah (peradangan), suhu tubuh naik, atau kehilangan fungsi-fungsi fisiologis. Hal tersebut merupakan respon protektif awal tubuh dalam upaya menghalangi patogen dan menghancurkannya (Galindo dan Hosokawa, 2004).

Ikan hanya mensintesis satu kelas imunoglobulin (IgM). Pada ikan teleostei IgM serum bersifat tetramerik dan pada ikan-ikan bertulang rawan bersifat penta merik. IgM lebih efisien dibandingkan dengan IgG dalam aktivasi komplemen, opsonisasi, netralisasi virus dan aglutinasi. IgM dijumpai pada mukus ikan dan merupakan imunitas yang dimediasi oleh sel. Sel-sel sitotoksik $\mathrm{T}$ membantu membunuh sel-sel yang terinfeksi viral serta sel-sel abnormal (Lichtman dan Abul, 2005).

\subsection{Mekanisme sistem kekebalan spesifik}

Antibody akan disintesis ketika ada respon dari luar berupa antigen yang kemudian dipresentasikan oleh sel-sel yang bertugas mempresentasikan antigen (Antigen presenting cells, APCs), antara lain makrofag, sel-sel dendrit dan lymphocyte B (sel B). APCs akan mempresentasikan epitop (determinan antigen) kepada sel $\mathrm{T}$ helper melalui molekul MHC (Major histocompatibility comnplex) kelas II. Sel $\mathrm{T}$ akan menerima epitop-epitop tersebut menggunakan reseptor yang disebut TCR (TCell receptor). Setelah menerima kiriman epitop dari APCs, sel T helper kemudian meresponnya dengan mensekresi sitokin. Sitokin (seperti interleukin) tersebut selanjutnya diterima oleh sel B dan sel B akan merespon signal yang diterima dengan mengadakan proliferasi menjadi sel B memori dan sel-sel plasma. Sel B memori akan mengingat epitop yang pernah diterima dengan membentuk reseptor khusus yang secara spesifik mengenali epitop tersebut sehingga ketika epitop yang sama masuk ke dalam tubuh, dengan cepat akan dikenali oleh sel $B$ dan dengan segera akan direspon. Sedangkan sel-sel plasma bertanggung jawab terhadap sintesis antibody (protein immunoglobulin) yang bertugas menghancurkan antigen sasarannya bersama sel T killer (Kropshofer and Vogt, 2007).

Antigen yang semula ditangkap dan diproses oleh APC (lihat gambar 2), dipersentasekan ke reseptor pada sel Tc dan Th masing-masing dalam hubungan dengan MHC kelas I dan II. APC tersebut memproduksi dan melepas sitokin yang merangsang sel $\mathrm{T}$ untuk berproliferasi dan berdiferensiasi. Aktifasi sel $T$ oleh antigen spesifik menghasilkan sel $T$ memori yang dapat memberikan respon sekunder terhadap antigen yang sama. Sel $T$ memori merupakan sel yang dapat hidup lama dalam keadaan istirahat dan dapat diaktifkan monosit/makrofag (Subowo, 1993).

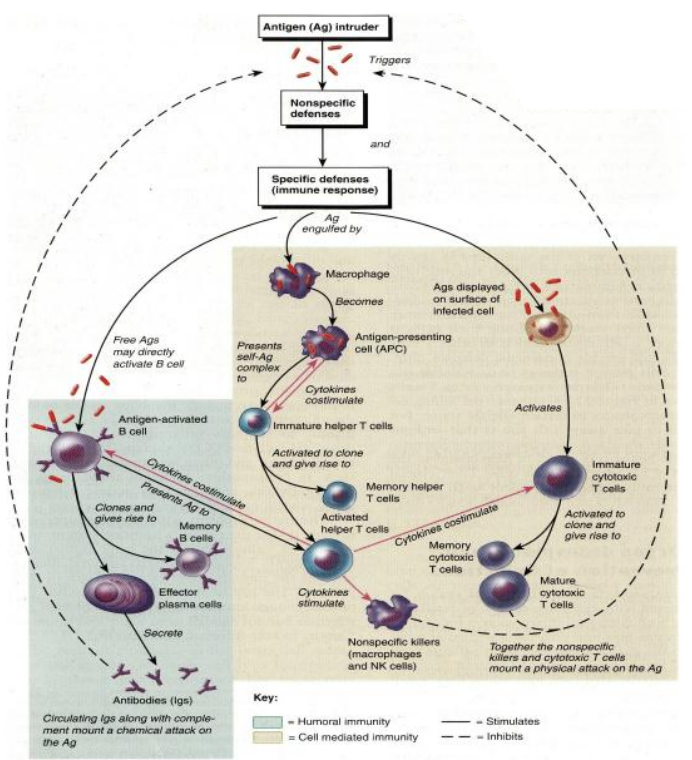

Gambar 2. Respon Imun specific melalui aktivitas seluler dan humoral.

Sel Th yang dirangsang melepas sitokin yang kemudian mengaktifkan sel $B$ dalam 3 tingkatan : aktivasi, proliferasi dan diferensiasi menjadi sel plasma yang akan memproduksi imunoglobulin (Ig). Sel B yang diaktifkan selanjutnya memproduksi Ig, sementara itu sel 